\title{
APRENDER A FILOSOFAR OU APRENDER A FILOSOFIA: KANT OU HEGEL?
}

Cesar Augusto RAMOS ${ }^{1}$

- RESUMO: O presente artigo pretende mostrar uma dupla perspectiva do ensino da filosofia proposto de forma disjuntiva: aprender a filosofar ou aprender a filosofia, representada, respectivamente, por Kant e por Hegel. A análise dessa questão será desenvolvida dentro do contexto da filosofia kantiana, nela destacando três aspectos: a) o ideal de perfectibilidade do gênero humano; b) o preceito da Aufklärung do pensar por si mesmo e o exercício crítico da razão, e c) a necessidade da coação como instrumento para o cumprimento do caráter normativo da conduta humana. Estes aspectos serão, também, abordados na filosofia de Hegel, bem como as suas conseqüências para o ensino da filosofia, e da possibilidade de uma escolha não disjuntiva de uma ou de outra perspectiva.

- PALAVRAS-CHAVE: Kant; Hegel; Educação; Ensino; Filosofia.

Aprender a filosofar ou aprender a filosofia? Esta é uma questão que se põe de forma incontornável sobre as possibilidades do ensino da filosofia. Se essa tarefa é desejável, de imediato uma outra pergunta decorre: de que forma e mediante quais métodos ou instrumentos é possível aprender a filosofar ou aprender a filosofia? Estas questões não traduzem apenas uma preocupação pedagógica do ensino da filosofia, mas envolvem, também, uma forma de se pensar e de realizar a própria filosofia.

Afinal, o que é propriamente filosofia? Esta é, para o desconsolo de muitos, uma das questões mais emaranhadas e que acompanha o próprio pensamento filosófico durante o longo trajeto histórico da sua constituição.

1 Professor Adjunto do Departamento de Filosofia e do Programa de Pós-Graduação em Filosofia da Pontifícia Universidade Católica do Paraná-Puc/PR. Artigo recebido em set/07 e aprovado em dez/07. 
Não pretendo aqui abordar esse assunto, não só porque não é o objetivo deste texto, como também não me sinto autorizado a fazê-lo de forma satisfatória. Apenas quero ressaltar que, no caleidoscópio conceitual da filosofia, um sentido fortemente consensual parece impregnar o conhecimento filosófico: é desejável que ele seja crítico, pois, assim, não se deixa dormitar na senda das verdades dogmáticas, como também se afasta da vala comum das visões de mundo simplistas e ingênuas. Ao mesmo tempo, é bom que a filosofia se apresente como um conjunto sistemático de idéias com rigor conceitual e especificidade terminológica.

Por ser crítico, o conhecimento filosófico não compartilha com as visões teóricas que, a despeito do rigorismo interpretativo, pretendem se arvorar em filosofias únicas, monopólios das visões da realidade: daquilo que é possível conhecer, do que podemos fazer e como devemos agir. A filosofia é diversa, e a sua variegação permite falar de filosofias e não da filosofia. São elas que constituem um acervo de conhecimento consubstanciado na história do pensamento. Além de crítica, ela se constitui no próprio processo da sua realização na história como o resultado sistemático e rigoroso do encadeamento de idéias que são produzidas para a sustentação, ampliação, ou substituição de teorias ou conceitos que têm vigência num determinado momento da história da filosofia. Por isso mesmo, não se pode inocentemente aderir à última moda de pensamento que aparece na vitrine das idéias para o consumo de espíritos ávidos de novidade.

Se a filosofia é, por sua própria natureza, um conhecimento crítico marcado pela diversidade e complexidade das teorias que a história do pensamento suscita e estimula -, como deve ser o seu ensino? Essa questão não deixa de incomodar a mente de filósofos, pedagogos, e professores de filosofia. Se, realmente, todos têm o interesse no aprendizado e na divulgação da filosofia como matéria importante, seja para a profissionalização do aluno como futuro professor e pesquisador, seja para a sua formação como pessoa e cidadão, o problema do seu ensino é relevante.

A tese que sustentamos é a de é preciso imbuir o aluno de uma perspectiva filosófica crítica, possível apenas quando se aprende a filosofar; mas, é necessário também apresentar o lado sistemático que se traduz pela apreensão de conteúdos escolásticos firmados nos diversos sistemas filosóficos da história da filosofia, momento em que se aprende os conteúdos da filosofia de um determinado filósofo ou de um sistema.

Kant e Hegel retratam essa dupla perspectiva. A produção filosófica destes pensadores traduz a possibilidade seja de uma filosofia crítica que nos incita a aprender a filosofar (Kant), seja de um saber sistemático que nos estimula a aprender a filosofia (Hegel). Não foram apenas pensadores originais e de grande densidade especulativa. Como professores demonstraram, também, tanto teórica como praticamente, grande interesse pela 
escola e pelo ensino, sobretudo, da filosofia. As suas idéias suscitaram derivações pedagógicas que são inerentes à forma como eles produziram filosofia: pelo aspecto crítico na lição que Kant nos lega; e pelo aspecto sistemático de um saber que se consubstancia como a razão de ser de um determinado momento da história, apreendido pela filosofia, e cuja realidade efetiva permite compreendê-lo racionalmente, segundo o ensinamento de Hegel.

Comecemos por Kant. Na opinião de Philonenko, Kant "foi um pedagogo durante toda a sua carreira" (PHILONENKO, 1980, p.10). ${ }^{2}$ Sob a influência do Emílio de Rousseau e de Basedow, o filósofo chega a dizer que "duas invenções dos homens podem ser consideradas as mais difíceis: a arte de governar e a arte de ensinar" (KANT, 1995a, p.703). A educação "é o mais importante e o mais difícil problema que o homem tem como tarefa... Por isso, ela só pode progredir na medida em que uma geração transmite à seguinte as suas experiências e os seus conhecimentos, e esta, por seu turno, dá a sua contribuição e lega para as seguintes..." (idem, p.702).

O sentido da pedagogia de Kant está atrelado a alguns princípios da sua filosofia. É possível destacar, para os nossos propósitos, pelo menos três aspectos, que irão determinar a sua visão de ensino, inclusive, da filosofia. São eles: a) o ideal de perfectibilidade do gênero humano; b) o preceito da Aufklärung do pensar por si mesmo e o exercício crítico da razão, e c) a necessidade da coação como instrumento para a realização dos fins racionais do caráter normativo da conduta humana.

No que diz respeito ao primeiro aspecto - o ideal de perfectibilidade do gênero humano -, tal tese significa dizer que o aperfeiçoamento da natureza humana constitui o telos, do qual a história se ocupa, e para o qual a educação contribui. Mas, quem deve ser o mestre? Qual é o modelo, o padrão que determina esse processo de aperfeiçoamento? Kant responde que é o ideal de humanidade demarcado como idéia reguladora que deve orientar o educador.

2 Como preceptor durante nove anos (1746/55) e, depois, como professor de Lógica e Metafísica na Universidade de Königsberg (1770/97), Kant se diferencia da condição intelectual e social dos outros professores e preceptores do seu tempo. Demonstra interesse na educação da criança numa época em que o ensino era reservado a quem não tinha preparo para fazer outra coisa. Também não havia estabelecimentos de ensino suficientes, e a idéia de educabilidade da infância, segundo exigências que lhes são intrínsecas, foi considerada importante apenas com Rousseau. "O século XVII, comenta Philonenko, não sabe o que é a criança. Aquilo que nós poderíamos chamar do 'sentido da criança' faltava totalmente no começo do século XVIII, e a idéia de ensino não encontra, por isso, nenhum fundamento sólido." (Philonenko, p.17). Com Rousseau essa ausência começa a ser superada: a criança não é mais um adulto em miniatura ou um pequeno homem, mas um ser que tem maneiras próprias de pensar, agir e sentir. 
Um princípio de pedagogia, que os homens, sobretudo para aqueles que propõem planos para a arte de educar deveriam ter ante os olhos é: as crianças não devem ser educadas segundo o presente estado da espécie humana, mas segundo um estado melhor, possível no futuro, isto é, segundo a idéia de humanidade e da sua inteira destinação. (idem, p.704)

O homem é perfectível porque é capaz de aprender o que lhe falta. Por este motivo, ele é passível de aperfeiçoamento pela educação. "O grande segredo da perfeição da natureza humana se esconde por detrás da educação" (idem, p.700). É dever do homem educar-se, tornar-se melhor, desenvolver todas as suas disposições e potencialidades, sobretudo, aquelas que dizem respeito à moralidade. Ao agir na formação do indivíduo, a educação porfia em desenvolver o ideal de humanidade que se conquista geração após geração. "É entusiasmante pensar que a natureza humana será sempre melhor desenvolvida e aprimorada pela educação, e que é possível chegar a dar aquela forma que é adequada à humanidade. Isto nos abre a perspectiva para uma futura felicidade da espécie humana" (idem, p.700). ${ }^{3}$

Um outro aspecto importante da filosofia de Kant, e que repercutirá na sua filosofia da educação, refere-se ao preceito da Aufklärung do pensar por si mesmo e o exercício crítico da razão. Este preceito está, também, formulado nas três máximas do juízo de gosto tal como o filósofo expõe na Crítica da Faculdade de Julgar $\S 40$, e que tem por título: "Do gosto como uma espécie de senso comunis". As três máximas são: "1. Pensar por si mesmo; 2. Pensar colocando-se no lugar do outro; 3. Pensar sempre de acordo consigo mesmo. A primeira máxima é a do pensamento livre do preconceito, a segunda máxima é aquela do pensamento alargado, a terceira máxima é a do pensamento conseqüente" (KANT, 1994, § 40, p.226).

A relação destas três máximas com o ensino, sobretudo as duas primeiras, retrata o ideal que elas representam. O preceito da máxima do pensar por si mesmo diz respeito ao ideal da autonomia da Aufklärung, ou seja, do pensamento livre, produzido por uma razão que não é passiva, mas esclarecida e que não tem necessidade de se guiar servilmente por outros. Contudo, esse preceito não reduz o pensamento ao monadologismo de uma racionalidade encerrada em si mesma, uma vez que a segunda máxima permite uma abertura ao pensamento dos outros, possibilitando o diálogo mediante o exercício de um "espírito aberto" (erweiterter Denkungsart). Esta máxima retrata um pensamento liberal que se regula não apenas por si mesmo, mas também corrige a sua auto-referencialidade ao se colocar sob a perspectiva

3 A idéia de uma "educação do gênero humano" - título da obra de Lessing, publicada em 1780 - é um dos temas que inspira a Aufklärung alemã. 
do outro. Desse modo, pode "elevar-se acima das condições subjetivas do juízo, nas quais tantos outros se colocam, e de poder refletir sobre seu próprio juízo a partir de um ponto de vista universal (que ele só pode determinar colocando-se sob o ponto de vista de outrem)" (idem, p.227). Assim, se o apelo ao pensar por si mesmo constitui a finalidade do ensino, norteando o seu método, o aspecto dialógico é indissociável ao aparente exclusivismo auto-referencial do pensamento.

O homem esclarecido realiza a íntima conexão entre a cultura e a autonomia moral e cognitiva com o objetivo de libertar-se das amarras da ignorância. "Sair da sua menoridade". Esse deve ser o lema para alcançar a independência moral e intelectual, e a educação deve ajudar a promovê-lo. Tal tarefa, contudo, necessita da força formadora do trabalho da disciplina com vistas à formar, mesmo que coercitivamente, a mente e o corpo do educando para os fins maiores da sua natureza: a maioridade mental e a autonomia ética da sua vontade.

A maioridade - desígnio da Aufklärung - é promovida, em parte, pela educação. Para isso, o ensino deve ser proposto tendo por base o princípio rousseauísta da atividade do próprio educando de modo a fazer com que ele mesmo alcance a autonomia. A educação deve ter por finalidade formar no educando o desejo de andar com as suas próprias pernas, e fazer com que ele tenha a coragem de fazer uso do seu próprio entendimento. Mas isso não se ensina. O educador não deve, portanto, tutelar o educando a ponto de intimidá-lo, criando uma personalidade dependente e temerosa ao risco do uso do seu próprio pensamento e da sua liberdade de ação para alcançar a maioridade.

A imensa maioria da humanidade (inclusive todo o belo sexo) considera a passagem à maioridade difícil e além do mais perigosa, porque aqueles tutores de bom grado tomaram a seu cargo a supervisão dela. Depois de terem primeiramente embrutecido seu gado doméstico e preservado cuidadosamente estas tranqüilas criaturas a fim de não ousarem dar um passo fora do carrinho para aprender a andar, no qual as encerraram, mostram-lhes em seguida o perigo que as ameaça se tentarem andar sozinhas. Ora, este perigo na verdade não é tão grande, pois aprenderiam muito bem a andar finalmente, depois de algumas quedas. (KANT, 1993a, p.53-4)

Na trilha da perspectiva socrática da autoprodução do conhecimento, o preceito kantiano do pensar por si mesmo - proposição emblemática da filosofia da Aufklärung - sustenta a pedagogia kantiana. O homem deve fazer de modo autônomo o bom uso da sua razão. "Sapere aude! Tem coragem de fazer uso do teu próprio entendimento" Este lema da Aufklärung deve orientar o ensino, sobretudo, da filosofia. A participação do mestre consiste em ajudar o aluno a aprender a filosofar, estimulando-o a exercitar a sua capacidade cognitiva como um instrumento racional autônomo de investigação 
da verdade. Sob pena de criar mentes servis, dependentes e tuteladas não devemos ensinar pensamentos, mas podemos ativar o exercício do pensar.

Se tenho um livro que faz as vezes do meu entendimento, um diretor espiritual que por mim tem consciência, um médico que por mim decide a respeito da minha dieta, etc, então não preciso de esforçar-me eu mesmo. Não tenho necessidade de pensar, quando simplesmente posso pagar; outros se encarregarão dos negócios desagradáveis (idem, p.53).

Mas, como se aprende a pensar? Qual deve ser o melhor método para o ensino da filosofia? O princípio geral que Kant segue é este: se há uma disposição natural para atividade do pensar, o seu livre exercício é o melhor instrumento para a produção do conhecimento. Assim como se aprende a nadar nadando, a andar andando, assim também se aprende a pensar pensando. Essa disposição necessita ser cultivada com a ajuda de um mentor, de um mestre que, ao proceder socraticamente, induz o educando a pensar por si mesmo sem a ação inibidora da tutela. O modo como se ensina e aprende filosofia deve ser coerente quanto ao próprio modo de produção do seu conhecimento: ela não é uma ciência acabada. Por esta razão, deve-se exercitar o seu uso criticamente.

Dentre todas as ciências racionais (a priori), portanto, só é possível aprender Matemática, mas jamais Filosofia (a não ser historicamente); no que tange à razão, o máximo que se pode é aprender a filosofar...Só é possível aprender a filosofar, ou seja, exercitar o talento da razão, fazendo-a seguir os seus princípios universais em certas tentativas filosóficas já existentes, mas sempre reservando à razão o direito de investigar aqueles princípios até mesmo em suas fontes, confirmando-os ou rejeitando-os. (KANT, 1995b, p.699-700)

No Curso de Lógica, a mesma idéia: "aprende-se a filosofar pelo exercício e pelo uso que se faz para si mesmo de sua própria razão... A verdadeira filosofia deve, pois, fazer, pensando por ela mesma, um uso livre e pessoal de sua razão e não imitar servilmente" (KANT, 1996, p.448-9). Com base no princípio do pensar por si mesmo, mediante o qual a filosofia é aprendida pela atividade do próprio ato do filosofar, a Metafísica dos Costumes, na parte dedicada à Doutrina da Virtude, faz algumas considerações pedagógicas práticas sobre o ensino, sobretudo, o da ética. O ensino deve ser conduzido não por meio de palavras e exortações que colocam o aluno na condição passiva de meros ouvintes, mas mediante questões "quando o mestre pergunta aos seus alunos aquilo que deseja ensinar-lhes" (KANT, 1993b, p.618). Este método, chamado de "erotético" (erotematische Methode), pode ser

um modo de ensino dialógico, quando o mestre interroga a razão do aluno, ou um modo catequético, quando ele simplesmente se dirige à memória deste úl- 
timo. Pois, se alguém interrogar alguma coisa à razão de outrem, só pode fazêlo dialogicamente, quer dizer, mediante questões e respostas que professor e aluno trocam um com o outro. Por estas questões, o mestre orienta o pensamento do seu discípulo. Assim, por meio de casos que o mestre propõe (ele é a parteira dos pensamentos do aluno), disposições do aluno são desenvolvidas e o discípulo se convence, deste modo, que ele mesmo é capaz de pensar; e fornece ao mestre, por sua vez, (sobre a obscuridade ou sobre a dúvida suscitada por certas proposições recebidas) a ocasião para ele aprender por si mesmo - conforme o dito docendo discimus [ensinando, aprendemos] - como ele deve bem interrogar. (idem, p.618)

O educador não deve, também, transformar o educando em mero depositário de informações, pois, o efeito passivo de acúmulo do conhecimento com pretensões meramente eruditas desestimula o homem a pensar por si mesmo, além de torna-se um saber pedante e estéril. "De um homem que não pensa por si mesmo, mas que pode aprender muito se diz que é um espírito limitado. Pode-se ser um homem de uma vasta erudição... e, no entanto, ser muito limitado no uso do seu saber histórico" (KANT, 1995c, p.423).

O terceiro aspecto da filosofia de Kant com evidentes implicações na educação - a questão da necessidade da coação como meio para o cumprimento racional da normatividade da conduta humana - será apresentado sob a forma de um aparente paradoxo na filosofia kantiana. Ele pode ser formulado do seguinte modo: se a educação eleva o homem à sua maioridade em que medida é possível, em nome do ideal da perfeição do homem e do gênero humano, legitimar uma pedagogia fundada na coerção? Ou ainda, a necessária imposição de conteúdos pedagógicos não poderia transformar a educação em adestramento, ferindo, assim, o princípio basilar da Aufklärung da autonomia da pessoa e do pensar por si mesmo?

O homem esclarecido e autônomo rejeita a coação, mas para chegar a essa grandeza moral ele precisa ser educado e coagido. Não há aqui um evidente paradoxo entre o ideal da autonomia e o mecanismo pedagógico da coação (Zwang) como elemento disciplinador? Como é possível tornar o

4 O método socrático (a maiêutica) a que Kant faz menção explícita deve ser empregado no ensino, sobretudo, no ensino da ética. Mas ele tem ressalvas. "Para o aluno principiante, o primeiro e mais essencial instrumento de ensino da doutrina da virtude é uma catequese moral... O princípio formal de tal instrução não permite, entretanto, o diálogo socrático a título de meio para ensinar com essa finalidade, visto que o aluno não faz idéia de que questões formular, de modo que exclusivamente o mestre executa o ensinamento. Mas a resposta que ele metodicamente extrai da razão do aluno deve ser exprimida e resumida em fórmulas que ele dificilmente transforma, a fim de que elas sejam consignadas na memória do aluno. Deste modo, é nisto que o método de ensino por catequese difere tanto da maneira dogmática (na qual somente o mestre fala), quanto da maneira dialógica (na qual tanto o mestre quanto o discípulo fazem perguntas e oferecem respostas mutuamente)" (ibid., p.618) 
princípio kantiano da dignidade da pessoa, segundo o qual o indivíduo deve ser tratado sempre como fim na sua humanidade, compatível com a ação interveniente de elementos externos que promovem a coerção, oriunda do direito, da educação e da política? É exatamente por causa deste paradoxo que a "educação é o maior e o mais difícil problema que pode ser proposto aos homens"(KANT, 1995a, p.702). Como Kant resolve esta aparente aporia?

Como se vê, a principal dificuldade é pensar de que forma a externalidade dos agentes coatores (a norma jurídica, o educador, o Estado) se impõe como um dever para o homem sem que essa imposição resulte em heteronomia, cujo móvel não é o próprio querer do indivíduo e o respeito à sua pessoa, mas uma ação que obriga de fora e contradiz o dever moral. O problema da coerção consiste, então, em saber se ela é legítima não só no campo da moralidade, como também no âmbito jurídico, político e educacional pela imposição de regras à vontade sem ferir a autonomia moral.

Kant define a coerção como "toda restrição de liberdade pelo arbítrio de um outro (Willkür eines anderen)" (KANT, 1993c, p.144). Se a coerção for interna (Selbstzwang), isto é, quando é exercida pela vontade (Wille) em relação ao arbítrio (Willkür), ela é legítima uma vez que é executada pela própria ação constrangedora do dever que o imperativo categórico traduz. Esta coerção se aplica apenas aos seres humanos que podem transgredir a lei moral em decorrência da sua liberdade de escolha. Se a coerção for externa, ou seja, exercida mediante uma autoridade diante da qual se tem o dever de obediência, então a legitimidade vem dessa autoridade.

A coação interna ou autocoação é aquela que é exercida pela razão prática, na figura de uma vontade (Wille) legisladora, sobre a outra face do querer humano responsável pela capacidade de escolha (Willkür), a partir da força coatora que o conceito de dever moral encerra.

Uma vez que o ser humano é um ser livre (moral), o conceito do dever não pode conter nenhuma outra coação a não ser a autocoação (Selbstzwang) - apenas representada pela lei - quando se trata da determinação interna da vontade (os móbeis). Pois, somente assim é possível unir este constrangimento (Nötigung) - mesmo se for externo - com a liberdade da vontade-arbítrio (Willkür), mas, deste ponto de vista, o conceito do dever torna-se um conceito ético. (KANT, 1993b, p.509)

Kant entende que há um poder de mando, que ele chama "autocracia" da razão prática, e que consiste na "faculdade de se tornar senhor das próprias inclinações quando estas são contrárias à lei" (idem, p.513). Por conta da constituição subjetiva da vontade humana, razão pela qual ela não é totalmente boa, faz-se necessário a coação da lei moral que deve preponderar sobre as inclinações. O mandamento (Gebot) tem o papel de representar um princípio objetivo (o imperativo) indispensável ao arbítrio e, assim, assegu- 
rar a "submissão à lei" e coagir o sujeito sensivelmente afetado. A lei prática só toma a forma de um imperativo para uma vontade que não é "santa", ou seja, para uma vontade que não é determinada unicamente pela razão, e que pode também ser "patologicamente afetada" pela sensibilidade.

Ora, para que o projeto rousseauísta da compatibilidade entre liberdade e obediência não seja paradoxal, é preciso compatibilizar as duas formas ou funções da vontade: a legislativa, diante da qual não há coerção, e é derivada do sentido da liberdade como autonomia, e a executiva, aquela que obedece a lei criada pela própria vontade. Esta última função necessita de coerção face à possibilidade de não seguir uma lei que a vontade estatuiu para ela mesma. Com essa distinção, coercividade e obediência não se opõem à autonomia. Ambas constituem, antes, um instrumento necessário para influenciar a capacidade de escolha (Willkür) quando patologicamente afetada. Essa coerção significa um constrangimento moral, uma "resistência oferecida pela razão prática, à qual se pode dar o nome de uma coação (Zwang) interna, mas de natureza intelectual" (KANT, 1993d, p.143).

Mas como harmonizar a autolegislação e autonomia com a coerção? No âmbito noumênico, essa equação não é objeto de suspeita, pois a coerção interna, enquanto faz parte da idéia de dever, apenas apresenta a sua face impositiva como decorrência do imperativo. A obediência, entendida como a submissão voluntária do mesmo agente a uma norma racional, não fere a autonomia. O conceito de obrigação (e de obediência) abarca o mesmo sujeito compreendido sob um duplo aspecto da sua faculdade unificada de volição: a face de um sujeito volitivo (Wille) que exerce a obrigação, constrangendo a vontade do arbítrio (Willkür) - sua outra face - a escolher a lei moral. A face do sujeito que obedece está, portanto, submetida à coação da própria vontade informada por princípios de uma razão prática.

Quanto à coação externa, ela pode ser produzida pelo mecanismo da natureza determinando aquilo que é, ou por forças produzidas pela ação humana no direito, na política e na educação. Do ponto de vista antropológico, Kant adota a idéia de que é "a maldade da natureza humana que torna necessária a coação"(KANT, 1993e, p.244). O homem só se torna bom quando é submetido a um poder que o obriga a ser bom, até que possa progressivamente alcançar a capacidade de, por vontade própria, tornar-se senhor do seu próprio destino. Até lá, ele necessita da força coagente das leis sociais e da educação que dispõem sobre os deveres, e cujo cumprimento envolve o conceito de coerção mediante a intervenção da lei, não necessariamente interna, mas cuja ação torna-a análoga ao mecanismo constrangedor da coercividade interna.

Todos os deveres contêm um conceito do constrangimento pela lei; mas deveres éticos envolvem um constrangimento interior, enquanto que deveres de direito 
implicam um constrangimento para o qual a legislação interna é, também, possível. Portanto, para os dois casos, seja o autoconstrangimento, seja a coerção por outrem, há a idéia da coação. (KANT, 1993b, p.525)

Ao fazer a distinção entre as leis do direito (Rechtsgesetze) e leis éticas (Sittengesetze) e a correspondente legislação - jurídica e ética - Kant introduz, na Rechtslehre a necessidade do uso da coerção no direito. "Com o direito liga-se, ao mesmo tempo, segundo o princípio de contradição, uma faculdade de coerção contra aquele que prejudica" (KANT, 1993f, p.339). Esta faculdade é legítima na medida em que se contrapõe a uma coerção injusta e não legítima. Quando um outro exerce uma ação invasiva e prejudicial ao campo legítimo de liberdade do sujeito, ele pode exercer um ato coercitivo de defesa contra essa ação. Que tipo de coerção é essa? Trata-se de um direito subjetivo que tem o indivíduo de reagir - buscando a sua própria defesa ou invocando o poder coercitivo do direito - contra atos ofensivos e injustos à sua pessoa a ao seu patrimônio.

O direito é uma necessidade racional decorrente da ação livre dos homens na sociedade que se externaliza em atos que precisam ser reciprocamente delimitados, de tal forma que a liberdade de cada um esteja de acordo com a liberdade de todos. A garantia da liberdade individual é possível pelo estabelecimento de leis, para cuja eficácia se faz necessário a coerção. "O direito consiste simplesmente na limitação da liberdade de outrem com a condição de que ela possa coexistir com a minha segundo uma lei universal" (KANT, 1993c, p.148).

Quando o filósofo diz que o "homem é um animal que necessita de educação" e, conseqüentemente, de disciplina, isso significa afirmar que ele tem necessidade de uma força exterior que o obriga incondicionalmente a se comportar segundo certos preceitos. Ou seja, de que ele é "um animal que, quando vive com os da sua espécie, tem a necessidade de um senhor" (KANT, 1993g, p.40). Por essa razão, Kant concebe uma constituição civil como uma relação de homens livres submetidos a leis públicas de coerção (Zwangsgesetze) universalmente válidas que asseguram a vida civil e os direitos.

Ora, a disciplina (e o seu caráter coagente) representa uma necessidade porque ela "procurar impedir que a animalidade prejudique o caráter humano, tanto do indivíduo como na sociedade" (KANT, 1995a, p.705). Afinal, é ela que impede o predomínio das inclinações animais, evitando que o homem se desvie do seu destino - a própria humanidade. Um dos princípios da ação pedagógica deve ser o exercício da coerção para a que a humanidade floresça no educando, e para que o uso da liberdade possa ser regulado de acordo com o princípio de que o livre-arbítrio de cada um seja compatível com o livre arbítrio de outrem segundo regras universais legítimas. 
A obediência constitui, portanto, um aspecto importante na organização da filosofia prática de Kant, enfeixada na idéia dos deveres jurídicos e das virtudes morais - duas formas de jurisdição da razão prática. Para que o homem possa afirmar a sua liberdade ele deve obedecer, seja ao imperativo do dever, seja ao imperativo do direito. Ambos exprimem as leis da razão, ou seja, a capacidade humana de se orientar pelo caráter normativo de uma racionalidade que implica a obediência à norma, de tal modo que um ato contrário ao dever constitui uma transgressão a essa normatividade. Atribuir a si mesmo uma lei supõe a idéia de que a vontade obedece a si mesma sem nenhuma violência à sua liberdade. A autonomia da razão prática transforma-se em poder de mando do sujeito (autocracia) e, simultaneamente, submissão voluntária a esse mando. Se o princípio supremo da educação é a "cultura da liberdade pela coerção", cabe a ela exercer o seu ofício no sentido de formar o indivíduo de modo a tornar compatível a sua liberdade com a obediência à coercividade de uma norma legítima.

Os três aspectos que apontamos na filosofia de Kant, e que repercutam na sua pedagogia e na aprendizagem da filosofia, estão, também, presentes na especulação hegeliana. Nela, estes aspectos adquirem um sentido próprio e original e que terão implicações diferentes na educação e no ensino da filosofia. ${ }^{5}$

No que se refere à questão da perfectibilidade do gênero humano, o idealismo kantiano da idéia reguladora da humanidade como modelo para o educador se traduz na filosofia hegeliana como possibilidade histórica objetiva. A inteligibilidade racional daquilo que está presente na história permite realizá-la como realidade efetiva (Wirklichkeit), e não mais como modelo,

5 Convém lembrar que Hegel dedicou toda a sua vida ao ensino nos diversos níveis da organização do sistema educacional de sua época. De 1793 a 1800, em Berna, trabalhou como preceptor. De 1808 a 1816 lecionou e ocupou cargo administrativo: foi nomeado por Niethammer diretor e professor de filosofia e religião num Colégio de Nuremberg. Em 1816 foi professor na universidade de Heidelberg, e a partir de 1818 em Berlin, de cuja universidade foi nomeado reitor no final de sua vida (1829/1831). Enquanto "pedagogo filósofo" - como ele mesmo se autodenominou numa carta a Niethammer de 23/10/1812 -, a educação significou, antes de tudo, uma tarefa prática. Contudo, como filósofo e motivado pela sua experiência de professor, Hegel deveria refletir sobre o significado da escola e do ensino, sobretudo, da filosofia. Mesmo assim, não escreveu de forma sistemática uma única obra sobre o assunto. Durante a sua estadia em Nuremberg redigiu os discursos ginasiais que eram lidos na cerimônia de formatura do Colégio. Nesse mesmo tempo, escreveu um manual didático para o ensino de filosofia e que se chamou Propedêutica Filosófica. Segundo Bourgeois, a posição hegeliana sobre os problemas pedagógicos, particularmente escolares e universitários, está encunciada, sobretudo, em "documentos de circunstância, mencionamos os cinco discursos de distribuição de prêmios pronunciados no Ginásio de Nuremberg, diversos relatórios administrativos, dois relatórios detalhados sobre ensino da filosofia no Ginásio - um de 1812 para a Baviera, outro de 1822 para a Prússia - e uma carta-relatório sobre o ensino da filosofia nas universidades, de 1816" (BOURGEOIS, 1978, p.23). 
em função do qual a ação educativa deve se ajustar. A partir desse ponto de vista, o realismo da Idéia hegeliana torna-se crítico face às filosofias do entendimento que alçam o ideal a um princípio abstrato e o entendem como algo dissociado da realidade. " ${ }^{~ " R e a l i d a d e ~ e ~ i d e a l i d a d e ~ s a ̃ o ~ c o n s i d e r a d o s ~ f r e-~}$ qüentemente como um par de determinações que se colocam um face ao outro, com igual subsistência para si, e se diz, em conseqüência, que fora da realidade há, também, uma idealidade" (HEGEL, 1995b, § 96).

Se a distância entre o ideal da perfectibilidade e a realidade deve ser superada, e se esta não é o outro, o antípoda do ideal, cabe à formação do homem, mediada pela educação e pela cultura, efetivar esse ideal que está presente na realidade histórica do espírito objetivo. O progresso da razão é o trabalho do espírito na busca do seu aperfeiçoamento, isto é, daquilo que ele é em si mesmo. "É aqui que se põe - diz Hegel - a questão da perfectibilidade e da educação do gênero humano. Aqueles que afirmaram esta perfectibilidade pressentiram alguma coisa da natureza do espírito, (...) e compreenderam que, quando ele (o espírito) concebe o que ele é, o espírito se dá uma figura superior àquela que constituía seu ser" (HEGEL, 1995a, § 343).

A formação do indivíduo para aquilo que o idealismo kantiano propõe como ideal da perfectibilidade do gênero humano constitui, para Hegel, uma forma de realidade que reúne o aspecto ideal do conceito e o aspecto real do seu ser-aí. A inserção da particularidade nesse universal retrata um processo de formação que exige instâncias mediadoras (a família, a escola, a educação) que propiciam o trabalho da negação da condição imediata (em-si) da natureza humana. O indivíduo, formado na universalidade da cultura (Bildung), realiza a sua humanidade, momento em que ele tem parasi a sua verdadeira natureza. Mediante a ação efetiva de formação que a sociedade oferece, o homem pode integrar-se à realidade do seu tempo, sem qualquer recurso externo propiciado pela abstração de um ideal regulador.

O que só é segundo seu conceito, o que é meramente em si, é somente imediato, apenas natural. Nós sabemos isso, também na representação. A criança é homem

6 A Filosofia do Direito declara o caráter concreto da sua pretensão de acordo com a palavra de ordem exposta na célebre passagem do Prefácio: "a tarefa da filosofia é conceber aquilo que é", ou seja, a Idéia. Nesse sentido, toda filosofia deve ser idealista: a "idealidade do finito é a proposição capital da filosofia, e toda verdadeira filosofia é por esta razão um idealismo" (HEGEL, Enzyk., I, Werke 8, § 95, An). O Prefácio à Filosofia do Direito adverte que a filosofia deve conceber e descrever o Estado como algo "racional em si" e evitar "construir um Estado tal como ele deve ser". Esse filósofo, entusiasta da Revolução Francesa e dos acontecimentos do seu tempo, para quem a leitura diária dos jornais constituía o melhor guia para a compreensão da realidade, sempre se colocou contra o romantismo subjetivista, as filosofias ingênuas e sentimentalistas e as utopias. Reafirma sua profissão de fé realista, declarando que "compreender aquilo que é, é a tarefa da filosofia, pois, aquilo que é, é a razão. Naquilo que concerne ao indivíduo cada um é filho do seu tempo (...)" (HEGEL, 1995a, p.26). 
em si, ela tem a razão apenas em si, ela só é a possibilidade de razão e de liberdade e, assim, livre apenas segundo o conceito. O que é primeiramente em si não está na sua realidade efetiva. O homem que é racional em si deve se atualizar no trabalho pela produção de si mesmo, saindo de si e, ao mesmo tempo, cultivando-se interiormente, de maneira a tornar-se racional para si. (idem, § 10)

A educação se insere no processo histórico de realização da liberdade segundo a concepção, disseminada pela Aufklärung, de melhoria do indivíduo e do gênero humano. Contudo, a meta do aperfeiçoamento se traduz no processo de formação do homem segundo um andamento paralelo à trajetória de realização e efetivação histórica do espírito, no sentido do melhoramento do gênero humano para a realização da liberdade. Há uma conexão entre a formação do indivíduo e a sua conseqüente elevação a um plano superior da humanidade, mediante o processo histórico de aperfeiçoamento que acompanha tanto um como outro. A consciência individual necessita se formar na trilha percorrida pela universalidade do espírito, e manifestar o ser-aí desta universalidade. O indivíduo precisa adquirir para si o saber e elevar-se à universalidade da cultura, paradigma da condição humana. Isso é possível pela cultura e pela formação educacional que requer esforço, trabalho e disciplina.

A formação (Bildung) é, por conseguinte, na sua absoluta determinação, a libertação e o trabalho da mais alta libertação, isto é, o ponto de passagem absoluto para a não mais substancialidade [ética] imediata, natural, mas à substancialidade espiritual, infinitamente subjetiva da eticidade, elevada igualmente à figura da universalidade. Esta libertação é no sujeito o duro trabalho contra a mera subjetividade da conduta, contra a imediatidade do desejo, assim como contra a vaidade subjetiva do sentimento e o arbítrio do capricho [...] É por meio deste trabalho de formação que a vontade subjetiva alcança em si mesma a objetividade, na qual unicamente, por sua parte, ela é capaz e digna de ser a realidade efetiva da Idéia. (idem, § 187)

Quanto ao segundo aspecto da tese kantiana do princípio da Aufklärung do pensar por si mesmo, e que orienta a concepção do ensino da filosofia voltada para a aquisição da habilidade cognitiva do filosofar, Hegel diz que essa habilidade só é conquistada mediante o ensino preliminar da própria filosofia. Nos seus escritos pedagógicos, sustenta a tese de que "o modo de proceder para familiarizar-se com a filosofia rica em conteúdo não é outro senão a aprendizagem. A filosofia deve ser ensinada e aprendida tanto quanto qualquer outra ciência" (HEGEL, 1996, p.411). Observa, ainda, que

tornou-se preconceito não só no estudo da filosofia, mas também da pedagogia - e aqui, todavia, em maior medida - que o pensar por si mesmo deveria ser desenvolvido e exercitado no sentido de que em, em primeiro lugar, nesse estudo o material não importa. E, em segundo lugar, a colocação do problema como se o aprender fosse 
oposto ao pensar por si mesmo, posto que de fato só se pode exercitar o pensar em um material que não seja o produto ou a elaboração de uma fantasia ou alguma intuição sensível ou intelectual, mas que é um pensamento e, ademais, um pensamento só pode ser aprendido mediante o fato de que ele mesmo é pensado. (idem, p.422)

Essa tese está calcada nas seguintes razões. Em primeiro lugar, só se pode aprender a filosofar quem antes aprendeu a filosofia. De modo análogo, só se aprende a pensar quando se compreende, pelo aprendizado, os conteúdos do pensamento. O filósofo adverte que a tese da moderna da pedagogia, ao recomendar que não se deve aprender a filosofia, mas sim a filosofar, incorre no mesmo equívoco do viajante que deve viajar e sempre viajar, sem aprender a conhecer os conteúdos geográficos e históricos das cidades: os rios, os países, os homens, etc. Quando se viaja, aquilo que se oferece ao viajante é conhecido no próprio ato da sua viagem. De modo semelhante, no ensino da filosofia ao se "aprender a conhecer o conteúdo da filosofia não se aprende apenas o filosofar, mas também já se filosofa efetivamente" (idem, p.410).

Em segundo lugar, só se aprende a filosofar quem possui pensamentos, os quais constituem o objeto da filosofia. Esta contém conteúdos verdadeiros que ela "reivindica como forma própria do seu empreendimento". Por isso, é de vital importância para quem quer exercitar o pensamento receber estes conteúdos especulativos já elaborados pelo espírito, e fazer deles o seu próprio pensamento, o que é possível pela mediação dos procedimentos pedagógicos de aprendizagem.

Para os neófitos, "cabeças ocas" sem nenhum conteúdo filosófico, este cuidado pedagógico é ainda mais necessário. No seu tempo, Hegel já se queixava da "divagação e da busca perene sem conteúdo" de um saber nãosistemático e destituído de rigor. Este procedimento é peculiar de uma atitude simplória de quem deseja filosofar, sem antes ter se dedicado ao duro trabalho de aprender a filosofia, e se aferra a fórmulas vazias "O raciocínio ou a especulação não sistemática tem, por conseqüência, o fato de que as cabeças estão vazias de todo pensamento, que elas não sabem nada" (idem, p.410-1). As coisas essenciais devem, simplesmente, ser aprendidas.

A representação peculiar e própria que a juventude tem dos objetos essenciais é, por um lado, ainda completamente indiferente e vazia, e, por outro lado, em sua infinitamente maior parte, apenas opinião, ilusão, meio-pensamento, distorção, carência de determinidade. (idem, p.412)

Como se caracteriza o ensino da filosofia? Hegel distingue dois níveis com conteúdos diferentes. Para o ginásio (com alunos na idade de 14/16 a 18/20 anos), a filosofia adquire a feição de um ensino propedêutico baseada em conteúdos da filosofia do entendimento. Estes conteúdos, embora abs- 
tratos, não adquirem ainda a forma da especulação, mas exercitam o pensamento do jovem estudante a pensar sem o apoio das representações concretas. No ginásio,

prepara-se mediante o pensamento abstrato e, em seguida, o pensamento dialético, e além disso mediante a aquisição da representação tendo um conteúdo especulativo. Uma vez que o ensino dos ginásios é, por essência, preparatório ele poderá se constituir, sobretudo, num trabalho dirigido sobre estes aspectos do filosofar. (idem, p. 416$)^{7}$

Após essa fase se introduz a forma dialética que desemboca na aprendizagem da forma especulativa e conceitual da filosofia, aquela que é ensinada na universidade, onde a filosofia propriamente dita deixa de ser disciplina preparatória e de cunho propedêutico, e passa a ser apresentada de forma especulativa segundo a ordem de exposição imanente do conceito. A despeito da importância do ensino da filosofia, é importante registrar que ele não tem por finalidade a edificação do estudante, induzindo-o à aquisição de virtudes que a filosofia, eventualmente, poderia oferecer. Para Hegel, o que dela se espera não é esse tipo de finalidade, pois, a filosofia "não deve ser nunca edificante (erbaulich), mesmo quando exposta à juventude" (idem, p.424). Ao ter por método a incorporação de conteúdos filosóficos, o seu ensino deve satisfazer, primordialmente, a necessidade de afastar o estudante de uma forma frívola de pensar conceitos e pensamentos confusos produzidos pela exacerbação subjetiva do sentimento e da fantasia.

Com efeito, o professor deve mostrar ao aluno que a forma assistemática e meramente opinativa de fazer filosofia leva a um relativismo estéril das idéias ou a uma presunção no conhecimento, propiciando a atitude não rigorosa e simplista de que cada um pode produzir a sua própria filosofia. Esse procedimento autoriza o professor a adotar uma postura esotérica, enigmática, obscura e, muitas vezes, pedante? Ainda que a filosofia hegeliana possa sugerir tal atitude, o próprio Hegel recomenda uma outra conduta pedagógica: "de uma forma mais precisa, a filosofia alcança mediante sua determinação a aptidão para ser aprendida apenas quando ela se torna clara, comunicável e capaz de converter-se em um bem comum" (idem, p.423).

7 Quanto à organização das matérias e assuntos filosóficos ministrados no ginásio, Hegel discorre sobre esse tema numa carta a Niethammer (23/10/1812), e num relatório sobre o Ensino da Filosofia nos Ginásios (7/2/1823), dirigido ao ministro do ensino do reino da Prússia. Nestes documentos, o filósofo propõe, além do estudo de elementos de lógica apresentada inteiramente à maneira antiga, o conhecimento da religião, do direito e dos deveres; o estudo da cosmologia, da teologia natural e da psicologia (as representações produzidas pelos sentidos, pela imaginação, pela memória e outras faculdades da alma); e elementos da enciclopédia filosófica para as classes superiores. 
O conteúdo filosófico já trabalhado, e que constitui o acervo de pensamentos da produção filosófica, deve ser aprendido pelo estudante. "O mestre o possui, ele o pensa primeiro, os alunos pesam-no em seguida" (idem, p.412). Cabe ao professor possuir este "tesouro" e transmiti-lo aos alunos que com eles se identificam, na medida em que têm o privilégio de acolher a filosofia que o mestre ensina. Refazer o caminho de uma filosofia originariamente elaborada em nada diminui a autonomia e a criatividade do aprendiz, pois, ele está reconstruindo no seu próprio espírito os momentos fundamentais do filosofar.

Quanto ao último aspecto, o da coercividade da educação, é preciso observar que tanto Kant como Hegel ressaltam a ação disciplinadora do educador. Sobre esse assunto, Hegel afirma que "o direito dos pais sobre o arbitrio (Willkür) dos filhos tem por finalidade mantê-los disciplinados e educá-los. O fim das punições não é a justiça como tal, mas de natureza moral: consiste em intimidar uma liberdade ainda prisioneira da natureza e em elevar a consciência e a vontade deles (filhos) à universalidade" (HEGEL, 1995a, § 174). A obediência, como resultado do esforço de identificação do educando aos conteúdos da aprendizagem, apenas confirma a necessidade dessa identificação produzida fora da família, no âmbito da escola.

Para Hegel, o caráter identificador da ação pedagógica que a escola produz tem um papel fundamental. A educação escolar ajuda a formar, para além da esfera imediata do sentimento e do amor familial, uma personalidade que, pela mediação de mecanismos de alteridade que a cultura produz, se eleva à esfera da universalidade concreta da cidadania. Por isso, a escola deve oferecer ao educando situações pedagógicas de um reconhecimento não excludente, pelas quais ele educa o seu espírito e está apto a integrar as instâncias éticas que representam a sua verdadeira natureza. Mas isso é feito com trabalho e disciplina. Por isso, o educador deve oferecer ao educando a força fecunda do negativo, propiciada por relações de alteridade que, no fundo, são mecanismos de coação legitimados pela idéia daquilo que é superior.

A escola, ao efetivar o momento dialético da negatividade educacional, se apresenta como o outro do educando. Enquanto o seu outro, os conteúdos escolares e acadêmicos representam para ele a sua própria essência "ex-posta" nestes conteúdos que devem impregná-lo, e com os quais ele deve se identificar. Isso é possível mediante os processos de reconhecimento, os quais permitem a absoluta inserção do educando no seu outro segundo o paradigma de uma intersubjetividade afirmativa e não excludente.

As determinações da imediatidade (em-si) devem progredir no sentido da sua exteriorização em um outro, condição do seu manifestar. As relações lógicas da alteridade indicam o processo constituinte da essência de algo a partir da alienação do 
sujeito no seu outro, isto é, na sua diferença. Isto significa dizer que cada um tem a sua determinação própria quando é submetido a um jogo de espelhamento, por meio do qual o indivíduo afirma a sua identidade remetendo-se ao seu outro, a sua face espelhar. (RAMOS, 2003, p.47)

O método pedagógico por excelência consiste, então, em ocupar o educando "de alguma coisa de não imediato, de estranho, de alguma coisa que pertence à lembrança, à memória e ao pensamento" (HEGEL, 1996, p.321). Como exemplo desse reconhecimento, Hegel sugere o estudo da cultura antiga como instrumento pedagógico que oferece um mundo "estranho e diferente", uma alteridade na qual o educando deve mergulhar e tem a oportunidade de "deixar seu próprio elemento e habitar, com Robinson, uma ilha longínqua" (idem, p.321). É no estudo das línguas e da cultura antiga (grego e latim) que devemos nos "impregnar do seu ar, de suas representações, de seus costumes, e mesmo se quisermos, de seus erros, assim como de seus preconceitos," (idem, p.318) acostumando o homem neste que foi o "paraíso do espírito humano" (idem, p.318).

Esse procedimento pedagógico de estranhamento do educando em formas de alteridade - que afinal espelham a sua própria natureza - antecipa e prepara o próprio processo de inserção do indivíduo na vida ética superior do Estado. Nestas formas, ele reconhece pelo trabalho e pela disciplina a sua própria identidade, superando a imediatidade (em-si) da sua condição. A forma social e política da universalidade inter-subjetividade da vida ética (Sittlichkeit) constitui - ao fim longo processo formador no jogo dialético das instâncias mediadoras do reconhecimento -, a verdadeira razão de ser do educando. São formas de uma sociabilidade representada pela expressão sintética da Fenomenologia: "um eu que é um nós e um nós que é um eu."

A inserção do indivíduo na universalidade é propiciada pelo trabalho da cultura (Bildung) que se perpetua como sua "segunda natureza", mas cujo objetivo último é a integração pacífica e voluntariosa do indivíduo como bom cidadão na esfera da vida ética e política. A consciência desta segunda natureza é o resultado do trabalho da educação e da cultura, e constitui a própria essência do indivíduo que ele reconhece como sua, e que está presente no aspecto objetivo da liberdade nas instituições éticas e políticas da Sittlichkeit.

O escopo de uma educação coerciva consiste em reconciliar o educando com as formas de uma vida superior. Ora, esse desejo do melhor não pode ser deduzido de um ideal de perfectibilidade e muito menos estar presente na consciência e no querer do educando. O princípio coator da pedagogia hegeliana faz dela, na verdade, um procedimento conservador, no sentido de que ela está voltada para o adulto; ou, mais precisamente, para o cidadão integrado na realidade efetiva do Estado. Por esse motivo, a ins- 
tância superior da Sitlichkeit fornece o paradigma último à educação. A rigor, a ação disciplinadora do educador antecipa as formas superiores de integração do indivíduo nesta instância, mediante mecanismos pedagógicos de introjeção na consciência e na ação do educando do propósito da boa cidadania. São mecanismos formadores diretivos, mas nunca repressivos, e repercutirão de forma decisiva na formação do caráter do futuro cidadão, no sentido da sua adequação e obediência ao poder reconciliador da universalidade do Estado, enquanto potência de agregação destituída de toda força opressiva. Para Hegel, portanto,

a relação mestre-educando representa uma matriz para a constituição ulterior de integração solidária da particularidade à universalidade, ou seja, a inserção pacífica do indivíduo educado às instituições éticas e políticas da Estado. Nessa integração, realiza-se o projeto hegeliano da reconciliação, no qual a ação pedagógica pensada no modelo da formação e da disciplina sem violência, constitui um aspecto essencial. (RAMOS, 2003, p.52)

A alternativa hegeliana para o problema, já antecipada por Rousseau e aprofundada por Kant, consiste em mostrar que o esquema da auto-referencialidade comporta a obediência a um outro que deve ser o próprio sujeito, e permite uma dimensão compatível da liberdade com a coerção implícita na norma. Se a liberdade tem este lado auto-referencial - e, nesse sentido, Hegel segue Kant - a questão do vazio entre a liberdade do sujeito e a as normas sociais e legais não é resolvida pelo caráter normativo no campo das ações políticas e sociais reguladas pelo direito. Este caráter revela apenas uma liberdade reciprocamente limitada pelos arbítrios segundo o esquema da liberdade negativa como ausência de impedimentos que, indevidamente, obstaculizam a ação, pois, estão assentadas segundo o paradigma de uma sociabilidade excludente.

Para Hegel, obedecemos a nós mesmos e, na dimensão ética e político abrangente da Sittlichkeit, às normas legais e políticas. A liberdade, apesar de se apresentar na face de uma subjetividade auto-referencial, se efetiva pela face objetiva das instâncias da vida social mediadas pela categoria do mútuo reconhecimento. A auto-referencialidade da norma, que permite o consentimento do sujeito à lei que ele mesmo estatuiu, adquire, com Hegel, um estatuto normativo social e intersubjetivo. Esta deixa de ser endógena, e cuja força objetiva não decorre simplesmente da universalização da identidade racional de sujeitos auto-referentes. A proposta hegeliana procura compatibilizar a liberdade na sua dupla face: como direito da subjetividade (auto-realização) e, ao mesmo tempo, como direito da objetividade das instituições sociais e políticas, definindo, assim, a obediência ainda na perspectiva da adesão voluntária à norma, mas mediada pela categoria intersubjetiva do reconhecimento. 
O que se pode concluir sobre a questão proposta: aprender a filosofia ou aprender a filosofar? Trata-se, antes de tudo, de uma questão que não pode ser resolvida de forma disjuntiva. E isso por uma razão muito simples: se for verdade que se aprende a filosofia mediante o exercício do pensar, também é verdade que o filosofar depende da apreensão ou da aprendizagem de conteúdos filosóficos. Não seria essa uma relação de forma e conteúdo presente na filosofia e apropriadas ao seu ensino? Relação essa que se traduz no nexo entre dois aspectos: o lado auto-referencial do pensamento centrado na atividade do aluno e o lado hetero-referencial focado em conteúdos alheios ao educando, mas que devem ser reconhecidos como o seu próprio outro. É, precisamente, esta dimensão bipolar que constitui o caráter sempiterno e, por isso mesmo, desafiador da pedagogia.

Assim, é possível sustentar a tese de que a perspectiva crítica da filosofia é possível apenas quando se aprende a filosofar. Mas, é necessário, também, apresentar o lado sistemático que se traduz pela apreensão de conteúdos escolásticos firmados nos diversos sistemas filosóficos da história da filosofia, momento em que se aprende os conteúdos da filosofia, seja de um determinado pensador, seja de um determinado sistema filosófico. Kant tem razão. Hegel não menos, precisamente porque, sem abandonar o espírito da pedagogia kantiana, vê a filosofia e o seu ensino na perspectiva compreensiva da relação reciprocamente constituinte entre o ideal e o real, entre aprender a filosofia e aprender a filosofar.

RAMOS, Cesar Augusto. Learning philosophize or learn philosophy: Kant or Hegel? Trans/Form/Ação, (São Paulo), v.30(2), 2007, p.197-217.

- ABSTRACT: The present article intends to show the double perspective of philosophy teaching set forth in a disjunctive form: to learn how to philosophize or to learn philosophy represented respectively by Kant and Hegel. The analysis of this matter will be developed in the kantian philosophy context pointing out its threefold aspects: a) the ideal of perfectibility of the humankind; b) the Aufklärung precept of using one's own intellect and the critical use of reason, and c) the need of coercion as an instrument for the fulfillment of the normative feature the human conduct. These aspects will also be dealt within Hegel's philosophy, as well as its consequences for the teaching of philosophy, and the possibility of a non-disjunctive choice of either perspective.

- KEYWORDS: Kant; Hegel; Education; Teaching; Philosophy. 


\section{Referências bibliográficas}

BOURGEOIS, B. La Pédagogie de Hegel, in HEGEL, G. W. F. Textes pédagogiques, trad. B. Bourgeois, Paris: Vrin, 1978.

HEGEL, G.W.F. Grundlinien der Philosophie des Rechts oder Naturrecht und Staatswissenschaft im Grundrisse, Werke 7, Frankfurt am Main: Suhrkamp, 1995a.

Enzyklopädie der philosophischen Wissenschaften im Grundrisse I, Werke 8, Frankfurt am Main: Suhrkamp, $1995 \mathrm{~b}$.

Nürnberger und Heidelberger Schriften 1808-1817. Werke 4, Frankfurt am Main: Suhrkamp, 1996.

KANT, I. Beantwortung der Frage: Was ist Aufklärung? In: Immanuel Kant Schriften zur Anthropologie, Geschichtsphilosophie, Politik und Pädagogik 1. Band XI. Werke in swölf Bänden, Herausgegeben von W. Weischedel, Frankfurt am Main: Suhrkamp, 1993a. (Tradução portuguesa de Raimundo Vier. In: Immanuel Kant. Textos seletos, Petrópolis: Vozes, 1974).

Die Metaphysik der Sitten. Tugendlehre. Band VIII. Band IV, Werke in swölf Bänden, Herausgegeben von W. Weischedel, Frankfurt am Main: Suhrkamp, 1993b.

Über den Gemeinspruch: das mag in der Theorie richtig sein, taugt aber nicht für den Praxis. In: Immanuel Kant Schriften zur Anthropologie, Geschichtsphilosophie, Politik und Pädagogik 1. Band XI. Werke in swölf Bänden, Herausgegeben von W. Weischedel, Frankfurt am Main: Suhrkamp, 1993c.

Kritik der praktischen Vernuft, Band XI. Werke in swölf Bänden, Herausgegeben von W. Weischedel, Frankfurt am Main: Suhrkamp, 1993d.

Zum ewigen Frieden. In: Immanuel Kant Schriften zur Anthropologie, Geschichtsphilosophie, Politik und Pädagogik 1. Band XI. Werke in swölf Bänden, Herausgegeben von W. Weischedel, Frankfurt am Main: Suhrkamp, 1993e.

Die Metaphysik der Sitten. Rechtslehre. Band VIII, Werke in swölf Bänden, Herausgegeben von W. Weischedel, Frankfurt am Main: Suhrkamp, $1993 f$.

Idee zu einer allgemeinen Geschichte in Weltbürgerlicher Absicht. In: Immanuel Kant Schriften zur Anthropologie, Geschichtsphilosophie, Politik und Pädagogik 1. Band XI. Werke in swölf Bänden, Herausgegeben von W. Weischedel, Frankfurt am Main: Suhrkamp, 1993g.

Kritik der Urteilskraft, Band X, Werke in swölf Bänden, Herausgegeben von W. Weischedel, Frankfurt am Main: Suhrkamp, 1994.

Über Pädagogik. In: Immanuel Kant Schriften zur Anthropologie, Geschichtsphilosophie, Politik und Pädagogik 2. Band XII. Werke in swölf Bänden, Herausgegeben von W. Weischedel, Frankfurt am Main: Suhrkamp, $1995 \mathrm{a}$ 
KANT, I. Kritik der reinen Vernuft 2. Band IV. Werke in swölf Bänden, Herausgegeben von W. Weischedel, Frankfurt am Main: Suhrkamp, 1995b. (Tradução portuguesa de Valério Rohden e Udo Moosburger. In Crítica da razão pura, São Paulo: Nova Cultural, 1999).

Anthropologie in pragmatischer Hinsicht. In: Immanuel Kant Schriften zur Anthropologie, Geschichtsphilosophie, Politik und Pädagogik 2. Band XII. Werke in swölf Bänden, Herausgegeben von W. Weischedel, Frankfurt am Main: Suhrkamp, 1995c.

Logik. In: Schriften sur Metaphysik und Logik 2. Band VI, Werke in swölf Bänden, Herausgegeben von W. Weischedel, Frankfurt am Main: Suhrkamp, 1996.

PHILONENKO, A. Kant et le problème de l'éducation. In: KANT, I. Réflexions sur l'éducation. Trad. A. Philonenko, Paris: Vrin, 1980.

RAMOS, C.A. A pedagogia de Hegel e a ação formadora da alteridade cultural, In: Revista de Filosofia da PUCPR, vol. 15, n. 16, 2003, p.47. 